\title{
1 Breeding maize for traditional and organic agriculture
}

3 Pedro Revilla*a, Jose Ignacio Ruiz de Galarreta ${ }^{\mathrm{b}}$, Rosa Ana Malvar ${ }^{\mathrm{a}}$, Arsenio Landa ${ }^{\mathrm{c}}$, Amando Ordás ${ }^{\mathrm{a}}$

4

5 a Misión Biológica de Galicia, Spanish Council for Scientific Research, Apartado 28, 36080 Pontevedra,

6 Spain

7 'NEIKER-Instituto Vasco de Investigación y Desarrollo Agrario. 46, 01080-Vitoria, Spain

8 'Promotora Orxeira S.A, Ermille, 32897 Lobeira, Ourense, Spain

9

$10 *$ Corresponding author: previlla@mbg.csic.es, Phone 34986854800, Fax 34986841362

11 


\section{Abstract}

2 Breeding maize (Zea mays L.) for traditional agriculture can increase quality and added value of

3 agricultural products and allow the recovery of traditional foods. The objectives of this work were to

4 evaluate improved open-pollinated populations under organic and conventional agriculture in order to

5 determine the effects of selection for yield and flour yield and the relationship between agronomic and

6 quality traits under both cropping systems. We have selected open-pollinated maize populations for flour

7 yield and bakery quality under organic conditions, improved them under conventional conditions and

8 evaluated the breeding programs under organic and conventional conditions. Breeding was efficient for

9 grain and flour yield under organic agriculture for Meiro (an open-pollinated population with black

10 grains) but not for the other populations neither in organic nor in conventional conditions. Yield ranks of

11 varieties were moderately correlated under both conditions, and genotype $\times$ environment interaction (GE)

12 was significant for most traits when the analyses of variance were made over all environments but also

13 when organic and conventional environments were separated. GE was higher under organic agriculture.

14 Correlations between traits were higher under conventional agriculture and there were important

15 discrepancies between correlations in organic and conventional agriculture. We concluded that selection

16 under conventional agriculture was efficient for one population under organic agriculture. Selection under

17 the target environment could increase the possibilities of success.

18

19 Key words: organic agriculture; yield; quality; germplasm; breeding

20 
3 Traditional agriculture was similar to organic agriculture until the advent of inorganic fertilizers and

4 phytosanitary synthetic products in the second half of the Twentieth Century. According to Kovacevic

5 and Lazic (2012), organic agriculture is based on strong ecological principles and the absence of

6 application of agrochemicals, GMO, etc. Organic agriculture is a holistic way of farming besides

7 production of goods of high quality; conservation of the natural resources and richness of biodiversity.

When breeding crops for traditional or organic agriculture, some breeders consider that selection

9 need not be accomplished under both organic and conventional agriculture because varieties developed

10 for conventional agriculture are also suitable for organic agriculture (Ardelean et al. 2012; Burger et al.

11 2008; Lorenzana and Bernardo 2008). Contrarily, other authors emphasize the need to develop effective

12 strategies for improving crop performance in organic systems through plant breeding and that varieties

13 should be improved for specific adaptation (Löschenberger et al. 2008; Murphy et al. 2005; Wolfe et al.

14 2008; Kovacevic and Lazic 2012; Van Bueren et al. 2011). These last authors have suggested that

15 breeding for organic conditions has specific requirements for some crops and that cultivars that perform

16 very well under conventional agriculture are not interesting for organic agriculture. Nevertheless, no

17 specific maize breeding program has been reported so far although Rodrigues de Oliveira et al. (2011)

18 point out that election of base breeding material must be made in the specific environment for the

19 expression of favorable alleles that confer advantages for adaptation to this system. Some authors also

20 tested under organic conditions hybrids released under conventional conditions and found an acceptable

21 agreement (Lorenzana and Bernardo 2008; Burger et al. 2008); however, yield was reduced under organic

22 conditions (Burger et al. 2008). Several breeders have released improved varieties under conventional

23 agriculture, but there are few reports of plant breeding under organic agriculture.

24 Maize open-pollinated populations have been cultivated for centuries in traditional agriculture

25 and selected for adaptation and quality but have lower yield than modern hybrids under conventional

26 agricultural conditions. Since the introduction of maize in Europe, diverse maize varieties have been

27 selected for adaptation to a wide range of environments and consumer preferences. Such wide genotypic

28 and environmental diversity can have caused also significant genotype $\times$ environment interactions with

29 specific adaptation to environmental conditions and farmer's preferences (Duarte et al. 2005; LeFord and

30 Russell 1985; Malvar et al. 2008; Revilla et al. 2008). 
Maize was traditionally used for bread, which is a peculiarity of the north of Spain and Portugal

2 but also of other countries. Maize bread is made traditionally with whole flint maize grains. Consumers

3 prefer flint grains because their flour has better cooking characteristics and flavor than dent grains (Landa

4 et al. 2006). Quality requirements are important for human consumption (Watson 1988) but bread quality

5 is not defined for maize as for wheat and baking quality is lower for maize than for wheat (He and

6 Hoseney 1991). Although there are no defined criteria for bakery quality for maize bread, some criteria

7 are generally accepted, such as large grain size, uniformity, high density, and lack of physical damage,

8 pests, and diseases (Alonso-Ferro et al. 2008; Serna-Saldivar et al. 2001; Watson 1988). Yellow maize is

9 used normally for feed because it is a source of carotenoids for animals (Troyer 1999), while white maize

10 is preferred for human consumption because pigments cause strong aroma and flavor when cooked

11 (Poneleit 2001). Moreover, yellow or black grains are preferred in some areas (Serna-Saldivar et al. 2001;

12 Landa et al. 2006). Actually, in previous studies we concluded that differences in pigment content are

13 directly related to antioxidant activity in maize grains and that traditional methods for maize production

14 and processing maintained quality, pigment content and antioxidant activity (Revilla et al. 2012;

15 Rodríguez et al,. 2013).

Revilla et al. (2008) identified some local varieties with white, yellow, and black grains,

17 appropriate for bakery that performed well under organic agriculture. In that report we concluded that

18 there was no clear relationship between yield and quality and the varieties improved under conventional

19 agriculture are adequate for organic agriculture as well. Therefore, we began some breeding programs for

20 improving open-pollinated varieties for agronomic performance under conventional agriculture focusing

21 on traditional and organic agriculture.

With the introduction of hybrids under intensive cropping systems, the local populations and the

23 traditional uses of maize have been abandoned. The reintroduction of improved traditional varieties

24 suitable for organic agriculture and for manufacturing products for human consumption and organic

25 agriculture would fit the social demands for higher quality and safe foods. The objectives of this work

26 were to evaluate under organic and conventional agriculture several maize varieties improved for grain

27 yield or quality along with other open-pollinated populations of maize grown in the past by farmers under

28 traditional agriculture to find out if selection for grain yield and flour yield under conventional agriculture

29 was useful also for organic agriculture, and to investigate the relationship between agronomic and quality

30 traits under both cropping systems. 


\section{Materials and Methods}

3 Plant material and breeding programs

4 We evaluated for agronomic performance and grain quality under organic and conventional

5 agriculture ten open-pollinated populations, potentially valuable for maize bread or bakery use (Table 1).

6 Five of these open-pollinated populations (Donostia, Meiro, Rebordanes, Sarreaus, and Tuy) have been

7 improved for grain yield or flour yield during one or three cycles. The breeding program for Donostia was

8 carried out in the experimental field of NEIKER (Álava) and consisted on evaluating $100 \mathrm{~S}_{1}$ families and

9 recombining the $20 \mathrm{~S}_{1}$ families with the higher ability for making "talo", a kind of maize bread. One cycle

10 of selection was carried out. The breeding program for Meiro, Rebordanes and Sarreaus was carried out

11 in the experimental field of Misión Biológica de Galicia (Pontevedra) and consisted recombining the 20

$12 \mathrm{~S}_{1}$ families with highest flour yield and quality for maize bread from $100 \mathrm{~S}_{1}$ families. Flour yield was

13 obtained by multiplying yield by proportion of flour produced after grinding $50 \mathrm{~g}$ of whole grain in a

14 coffee mill for 1 minute, and sieving for 1 minute in a sieve with $1 \mathrm{~mm}$ orifices (Table 2). Quality for

15 maize bread was assessed by a panel that evaluated maize breads made from the $\mathrm{S}_{1}$ families with flour

16 yield above average. Bread was made following a traditional recipe (Revilla et al. 2008). Two cycles of

17 selection were carried out for those three populations. Finally, the breeding program for Tuy was carried

18 out in a similar way, but in this case the selection criterion was grain yield. Three cycles of selection were

19 carried out for this population.

\section{Experimental design}

22 The resulting 20 open-pollinated maize populations and improved cycles from northern Spain

23 and two commercial checks were evaluated in two farmers' fields in Galicia and in the Basque Country

24 under organic and conventional agriculture. Five organic environments and five conventional

25 environments were used between 2010, 2011 and 2012 (Table 2). The 22 genotypes were evaluated in

26 trials that followed an experimental design of randomized complete blocks with three replications. The

27 experimental plots of $10 \mathrm{~m}^{2}$ had a density of 60,000 plants ha $\mathrm{a}^{-1}$, with rows separated $0.8 \mathrm{~m}$ and plants

28 within rows $0.21 \mathrm{~m}$. Agricultural practices followed the recommendations of organic agriculture, i.e.

29 nutrients were supplied by adding manure, weeds were removed mechanically, and no chemical treatment

30 was used. Under conventional agriculture, current practices were the usual in the area with inorganic 
1 fertilizers, use of herbicide and no irrigation. On each plot we measured early vigor (scale from $1=$ weak

2 to $9=$ vigorous on 5-week old plants), plant appearance (the same scale from 1 to 9 but after flowering),

3 days to silking, ears per plant, grain yield $\left(\mathrm{Mg} \mathrm{ha}^{-1}\right.$ at $140 \mathrm{~g} \mathrm{H}_{2} \mathrm{O} \mathrm{kg}$ ), flour yield $\left(\mathrm{Mg} \mathrm{ha}^{-1}\right.$ calculated as

4 described above for the selection programs), grain moisture $\left(\mathrm{g} \mathrm{kg}^{-1}\right), 100$ grain weight, milling test $(\%$ of

5 grinds), and grain density $\left(\mathrm{g} \mathrm{ml}^{-1}\right)$. Milling test was an estimation of the resistance of grains to produce

6 flour in a laboratory mill; it was defined as the percentage of flour produced in a limited time. The milling

7 test consisted on grinding $50 \mathrm{~g}$ of whole grain in a coffee mill for 1 minute, sieving for 1 minute in a sieve

8 with $1 \mathrm{~mm}$ orifices, and weighting the remaining fraction. Milling test was calculated as $100 \times($ grain

9 weight - remaining fraction) / grain weight. The method for estimating grain density was to pour $50 \mathrm{~g}$ of

10 whole grain in a test-tube containing $50 \mathrm{ml}$ of $95 \%$ ethanol, and to record the final volume of the mixture.

11 Grain density was estimated as grain weight / (final volume - initial volume).

13 Statistical analyses

14 Analyses of variance were carried out using the procedure GLM of SAS (SAS Institute Inc.

15 2010) with 10 environments. Each environment is the combination of one year and one location. Five

16 environments were under conventional conditions and 5 under organic conditions. First, we made

17 combined analyses of variance over the ten environments in order to check the genotype $\times$ environment

18 interaction (GE) and considering random all effects except genotypes. We carried out analyses of

19 variance by type of agriculture (organic and conventional) and considering random all effects except type

20 of agriculture. Then we carried out analyses of variance by environment in order to check if interactions

21 were of rank or of magnitude, considering also random all effects except genotypes. Comparisons of means were made by using the Fishers' protected LSD at $\mathrm{P}=0.05$. Pearson

23 (simple) and Spearman (rank) correlations were calculated between traits with the procedure CORR of

24 SAS. To analyze the efficiency of the selection programs, values of $0,1,2$, and 3 were assigned to the corresponding cycles of selection, and simple linear regression analyses incorporating random effects in

26 the model [environment and replication (environment)] were performed for yield, flour yield and milling test (dependent variable) and cycles of selection (independent variables). 


\section{Results}

3 The combined analyses of variance showed that differences between types of agriculture (organic or

4 conventional) were not significant for the main agronomic traits (grain moisture or yield) but differences

5 were significant for most quality traits, including 100 kernel weight, milling test and grain density (Table

6 3). Differences between varieties were significant for few traits and the triple interaction environment $x$

7 type $\times$ variety was significant for most traits.

8 When we checked the effects of selection for yield, flour yield, and milling test, we found out

9 that most regression coefficients were not significant, with most of the significant coefficients being

10 negative (Table 4). Only Meiro significantly increased flour yield under organic conditions while it

11 decreased for Sarreaus, and the response was not significant under conventional conditions. The response

12 was similar for yield, except for Donostia with a significant decrease of yield in both organic and

13 conventional conditions. For milling test, Rebordanes increased grain hardness under both conditions and

14 Sarreaus decreased hardness under conventional conditions.

15 In the combined analyses of variance over the ten environments, genotypes were significantly

16 different for all traits except early vigor, and environments for all traits except early vigor and plant

17 appearance. Genotype $\times$ environment interaction (GE) was significant for all traits except ears per plant

18 and grain density and interactions were mainly of rank. We carried out analyses of variance by type of

19 agriculture (organic vs. conventional) and found that the genotypes were significantly different for all

20 traits except early vigor, plant appearance and silking under conventional agriculture, and for all traits

21 except early vigor, silking, ears per plant and grain density under organic conditions. Environments were

22 also significantly different for most traits, and GE was significant for most traits including grain yield,

23 flour yield and grain moisture. Interactions were mostly of rank (Tables 5 and 6).

24 Combined means for flour yield were highest for the commercial checks and Meiro(P)C2 (Table

25 4). Ranks under organic and conventional conditions were similar. Both commercial checks had the

26 highest yield in both conditions. Many varieties were not significantly different for milling test from those

27 with hardest grains across conditions, namely Carballeira, Rebordanes, and Getaria. The softest grains

28 under organic conditions were those of Meiro(P)C2, and of NKThermo under conventional conditions,

29 while across conditions the softest grains were produced by Oroso, the commercial check PR36B08, and 
1 Sarreaus(P)C2. Rank correlations between organic and conventional conditions were moderate for milling

2 test $\left(\mathrm{r}^{2}=0.65, \mathrm{P}=0.001\right)$, flour yield $\left(\mathrm{r}^{2}=0.70, \mathrm{P}>0.001\right)$, and yield $\left(\mathrm{r}^{2}=0.69, \mathrm{P}>0.001\right)$ (Figure 1).

The highest and the lowest yielder for each location were different both between and among

4 organic and conventional conditions (Table 5). However, the most stable across organic conditions was

5 Meiro(P)C2 followed by Tuy(S)C2 and NKThermo. Under conventional conditions, the most stable was

6 the commercial check PR36B08.

GE was significant for milling test under conventional conditions but not under organic

8 conditions. Differences among genotypes were not significantly different for three organic and one

9 conventional environments. The hardest grains across locations were those of Rebordanes(P)C2 both

10 under organic and conventional conditions followed by Tuy (Table 6). The varieties with hardest grains

11 differed for each location except for Rebordanes(P)C2 and Carballeira that had the hardest grains in two

12 and three locations, respectively. Differences among genotypes for early vigor were not significant in

13 either type of agriculture, for plant appearance only in organic conditions, and for silking, ears per plant,

14 and grain density only in conventional conditions (Table 7). The varieties with fewer days to silking were

15 Sarreaus and its improved cycles, Donostia and its improved cycle, and Martikoenea, while those with

16 high yield, such as Meiro and its improved cycles and the commercial hybrid PR36B08, were among

17 those with the longest growth cycle. Grain moisture is another measure of earliness that has low

18 correlation with silking (Table 8) but varieties with lowest grain moisture had also few days to silking and

19 vice versa (Table 7). Varieties also performed differently for grain moisture under organic and

20 conventional conditions. Ears per plant were below one under organic conditions while most varieties had

21 around one ear per plant in conventional conditions and the lowest values were for Martikoenea followed

22 by DonostiaC1 and Txalin.

23 Correlations between traits under organic and conventional conditions were different for grain

24 yield and grain moisture under conventional $\left(\mathrm{r}^{2}=0.79 \mathrm{P}>0.01\right)$ and organic $\left(\mathrm{r}^{2}=-0.68 \mathrm{P}>0.01\right)$ conditions,

25 for flour yield with grain moisture under conventional $\left(\mathrm{r}^{2}=0.78 \mathrm{P}>0.01\right)$ and organic $\left(\mathrm{r}^{2}=-0.67 \mathrm{P}>0.01\right)$

26 conditions (Table 8). Silking and early vigor, and silking and plant appearance had significant correlation

27 under conventional conditions, but not under organic conditions. Agronomic traits had weak correlations

28 with quality traits, except for milling test that had a negative correlation with yield, flour yield, and grain

29 moisture; these correlations were even weaker under organic conditions 


\section{Discussion}

3 Breeding was efficient for Meiro that increased yield and flour yield only under organic conditions.

4 However, selection was not efficient for the other open-pollinated varieties. Other authors have shown

5 that intrapopulation recurrent selection with selfed families was efficient under conventional agriculture

6 (Romay et al, 2011, Vales et al. 2001, Weyhrich 1998). The explanations of our results could be that the

7 evaluation was carried out in different fields (with more stressful conditions) than those used for

8 selection, that the variability available for yield was not enough or was exhausted early, or that the

9 selection reached a ceiling for example in the second cycle of Tuy. Whatsoever the reason could be, it is

10 also true that the selection programs were similarly inefficient for yield and for flour yield both under

11 organic and conventional conditions. Accordingly, Burger et al. (2008) stated that no specific adaptation

12 to conventional or organic agriculture was observed in maize hybrids and concluded that including

13 organic experimental sites among the evaluation fields increased the chances of success when selecting

14 for organic conditions. Similarly, Lorenzana and Bernardo (2008) concluded that high-yielding cultivars

15 for organic systems can be developed by screening conventional inbreds and hybrids for their

16 performance under organic systems. Boller et al. (2008) concluded that varieties of grasses should be

17 chosen based on performance under organic conditions but yields in organic and conventional conditions

18 were high enough to expect that selection under either condition would be similarly efficient. However,

19 most of the breeding programs we carried out under conventional agricultural conditions in our station

20 were not efficient when evaluated under organic conditions, suggesting that breeding programs carried

21 out in the target environment could be more efficient, as other authors have concluded, e.g. Rodrigues de

22 Oliveira et al. (2011) believe that maize breeding for organic conditions should be carried out in the target

23 environment; Löschenberger et al. (2008) recommended a winter wheat breeding program specifically

24 designed for organic agriculture since the election of the base germplasm until the final evaluation; and

25 Murphy et al. (2005) recommend a specific method for breeding for organic conditions that they call an

26 evolutionary participatory breeding method for improving inbred small grain crop species on a large

27 number of low-input and organic farms.

28 In the current trials, GE was very important probably due to the variety of environments and

29 cultural practices involved; nevertheless, evaluations of wide collections of maize varieties for human

30 consumption under conventional or organic agriculture show large diversity also for the importance of 
1 GE (Duarte et al. 2005; LeFord and Russell 1985; Malvar et al. 2008; Revilla et al. 2008). Other reports

2 combining organic and conventional agriculture have shown inconsistent results concerning GE (Lazcano

3 et al. 2012; Ardelean et al. 2012).

Meiro(P)C2 and some of the commercial checks had the highest flour yield and, although the

5 rank for flour yield was not the same under organic and conventional conditions, there was a reasonable

6 agreement for the best and the worst genotypes. Grain yield was highest for both commercial checks,

7 followed by Meiro(P)C2 and Martikoenea. Milling test was not as discriminating as yield and many

8 varieties were not significantly different from those with hardest grains across conditions. Comparisons of

9 means were more discriminating under organic than under conventional agriculture because the organic

10 fields used here were less heterogeneous than the conventional fields and, thus, GE was higher under

11 conventional agriculture. Rank correlations between organic and conventional conditions were moderate

12 for flour yield, yield, and milling test. Other authors have reported low correlations between organic and

13 conventional conditions (Löschenberger et al. 2008). Burger et al. (2008) reported moderate phenotypic

14 correlations between organic and conventional agriculture for grain yield and strong correlation for grain

15 dry matter content but not consistent genotypic correlations for maize hybrids. Boller et al. (2008) found

16 good correlations between yield of grasses under organic and conventional conditions and Lorenzana and

17 Bernardo (2008) reported that genetic correlations for performance in the two production systems were

180.84 for grain yield; greater than 0.90 for grain moisture, plant height, and ear height; and about 0.50 for

19 root lodging and stay green for maize hybrids.

20 As the organic and the conventional trials were carried out in different locations we cannot make

21 direct comparisons between organic and conventional conditions. Nevertheless, genotypes performed

22 under organic conditions better than under conventional conditions for early vigor and plant appearance,

23 and had fewer days to silking, while conventional conditions were superior for ears per plant, yield and

24 flour yield, grain moisture (drier grains), 100 grain weight, and grain density; also grains were harder

25 under organic conditions. Burger et al. (2008) found that maize hybrids yielded $16 \%$ less under organic

26 than under conventional conditions. As a general trend, our open-pollinated varieties performed better in

27 the organic environments for vegetative traits and in the conventional environments for yield components.

28 Indeed, these results depend both on the genotypes and locations involved in these experiments.

The earliest varieties, based on flowering and grain moisture, were Sarreaus and its improved

30 cycles, Donostia and its improved cycle, and Martikoenea. The varieties with longest growth cycle had 
1 also the highest yield, such as Meiro and its improved cycles and some commercial checks. The

2 correlation between flowering and grain moisture was low, but several varieties performed differently for

3 grain moisture under organic and conventional conditions but there were also some agreements between

4 organic and conventional conditions.

Quality traits varied between organic and conventional conditions, as under organic conditions

6 grains were harder and had lower weight and density. Although quality is important for these populations

7 initially intended for human consumption, it is not clear which are the parameters that define quality. In

8 previous works we have considered that grain weight, milling test, and grain density were important

9 quality factors (Revilla et al. 2008) following a general opinion that considers purity of the white color,

10 large uniform size of grains, high specific density, hard endosperm, and white cob (Watson 1988). Here

11 we include black and yellow varieties because in these regions they are used also for human consumption.

12 The lack of response to selection for quality traits can be partially due to the genetic complexity involved

13 in its regulation (Alonso Ferro et al. 2008; Malvar et al. 2008).

14 Generally, correlations between traits were higher under organic than under conventional

15 conditions and correlations among traits under organic and conventional conditions were different for a

16 number of pairs of traits, such as grain yield and grain moisture under conventional and organic

17 conditions, which were both significant but with opposite signs, as were for flour yield with grain

18 moisture under conventional and organic conditions. There were also pairs of traits with significant

19 correlation under conventional conditions, but not under organic conditions; the reason for these

20 discrepancies could be that the conventional environments where the trials were carried out were more

21 similar to the environments used for selection than the organic environments. Besides, the relationships

22 between agronomic performance and quality were not strong, except for milling test that had a negative

23 correlation with yield, flour yield, and grain moisture; these correlations were even weaker under organic

24 conditions. In a previous work we also found a weak relationship between yield and quality under organic

25 conditions (Revilla et al. 2008).

26 As conclusion, breeding has been efficient for Meiro in organic conditions while for the other

27 populations was equally inefficient under organic and conventional conditions. The GE and the

28 complexity of these traits can be partially responsible for these negative results because their

29 improvement is not straightforward. 


\section{Acknowledgements}

2 Research was supported by the Spanish Plan for Research and Development (project code AGL2010-

3 22254), the Basque Government, and the Diputación Provincial de Pontevedra.

4

5 
References

3 Alonso Ferro RC, Malvar RA, Revilla P, Ordás A, Castro P, Moreno-González J (2008) Inheritance of quality and agronomic traits in hard endosperm maize for human food. J Agric Sci 146: 551-560.

5 Ardelean M, Cordea M, Haş V, Bors A (2012) G x E Interaction on yield stability of five sweet corn hybrids grown under different agricultural systems. Not Bot Hort Agrobo 40: 290-292

7 Boller B, Tanner P, Schubiger FX (2008) Breeding forage grasses for organic conditions. Euphytica 163: $459-467$

9 Burger H, Schloen M, Schmidt W, Geiger HH (2008) Quantitative genetic studies on breeding maize for adaptation to organic farming. Euphytica 163: 501-510

11 Duarte AP, Mason SC, Jackson DS, Kiehl JC (2005) Grain quality of Brazilian genotypes as influenced by Nitrogen level. Crop Sci 45: 1958-1964

13 He H, Hoseney RC (1991) Gas retention at different cereal flours. Cereal Chem 68: 334-336

14 Kovacevic D, Lazic B (2012) Modern trends in the development of agriculture and demands on plant breeding and soil management. Genetika 44: 201-216

Landa A, Revilla P, Malvar RA, Butrón A, Ordás A (2006) Maíz para panificación. Agricultura 886: 50617 509

18 Lazcano C, Revilla P, Malvar RA, Domínguez J (2011) Yield and fruit quality of four sweet corn hybrids (Zea mays) under conventional and integrated fertilization with vermicompost. J Sci Food Agric

21 Leford DR, Russell WA (1985) Evaluation of physical grain quality in the BS17 and BS1(HS)C1 synthetics of maize. Crop Sci 25: 471-476

23 Lorenzana RE, Bernardo R (2008) Genetic correlation between corn performance in organic and conventional production systems. Crop Sci 48: 903-910

25 Löschenberger F, Fleck A, Grausgruber H, Hetzendorfer H, Hof G, Lafferty J, Marn M, Neumayer A, Pfaffinger G, Birschitzky J (2008) Breeding for organic agriculture: the example of winter wheat in Austria. Euphytica 163: 469-480 quality and agronomic performance. Crop Sci 48: 1373-1381 
1 Murphy K, Lammer D, Lyon S, Carter B, Jones SS (2005) Breeding for organic and low-input farming

9 Revilla P, Landa A, Rodríguez VM, Romay MC, Ordás A, Malvar RA (2008) Maize for bread under systems: An evolutionary-participatory breeding method for inbred cereal grains. Renew Agric Food Syst 20: 48-55

Poneleit CG (2001) Breeding white endosperm maize, in: Hallauer A.R. (ed.) Specialty corns, $2^{\text {nd }}$ ed, CRC Press, Boca Raton, Florida pp. 235-273.

Revilla P, Landa A, Rodríguez A, Ordas A, Malvar RA (2012) Influence of growing and storage conditions on bakery quality of traditional maize varieties under organic agriculture. Crop Sci 52: 593-600 organic agriculture. SJAR 6: 241-247

Rodrigues de Oliveira L, Vieira Miranda G, Oliveira DeLima R, Vagno de Souza L, Cardoso Galvão JC, Cristina dos Santos I (2011) Combining ability of tropical maize cultivars in organic and conventional production systems. Ciência Rural 41: 739-745

Rodríguez VM, Soengas P, Landa A, Ordá, A, Revilla P (2013) Effects of selection for color intensity on antioxidant activity in maize (Zea mays L.). Euphytica 193: 339-345

Romay MC, Ordás B, Revilla P, Ordás A (2011) Three cycles of reciprocal recurrent selection in two Spanish maize synthetics. Crop Sci 51: 1016-1022

SAS Institute (2010) SAS Version 9.3. The SAS Institute, Cary, NC.

Serna-Saldivar SO, Gómez MH, Rooney LW (2001) Food uses of regular and specialty corns and their dry-milled fractions, in: Hallauer, A.R. (ed.), Specialty Corn. CRC Press, Boca Ratón, Florida, pp. 303-337

Troyer AF (1999) Background of U.S. hybrid maize. Crop Sci 39: 601-626

Vales MI, Malvar RA, Revilla P, Ordas A (2001) Recurrent selection for grain yield in two Spanish maize synthetic populations. Crop Sci 41: 15-19

Van Bueren ETL, Jones SS, Tamm L, Murphy KM, Myers JR, Leifert C, Messmer MM (2011) The need to breed crop varieties suitable for organic farming, using wheat, tomato and broccoli as examples: A review. Njas-Wageningen J Life Sci 58: 193-205

Watson SA (1988) Maize marketing, processing, and utilization, in: Sprague, G.F, Dudley, J.W. (eds.), Maize and maize improvement, $3^{\text {rd }}$ ed, Am. Soc Agron. Madison, Wisconsin, pp. 881-940 
1 Weyhrich RA (1998) Responses to seven methods of recurrent selection in the BS11 maize

2 population. Crop Sci 38: 308-321

3 Wolfe MS, Baresel JP, Desclaux D, Goldringer I, Hoad S, Kovacs G, Löschenberger F, Miedaner T, 4 Østergård H, Lammerts van Bueren ET (2008) Developments in breeding cereals for organic 5 agriculture. Euphytica 163: 323-346

6

7 


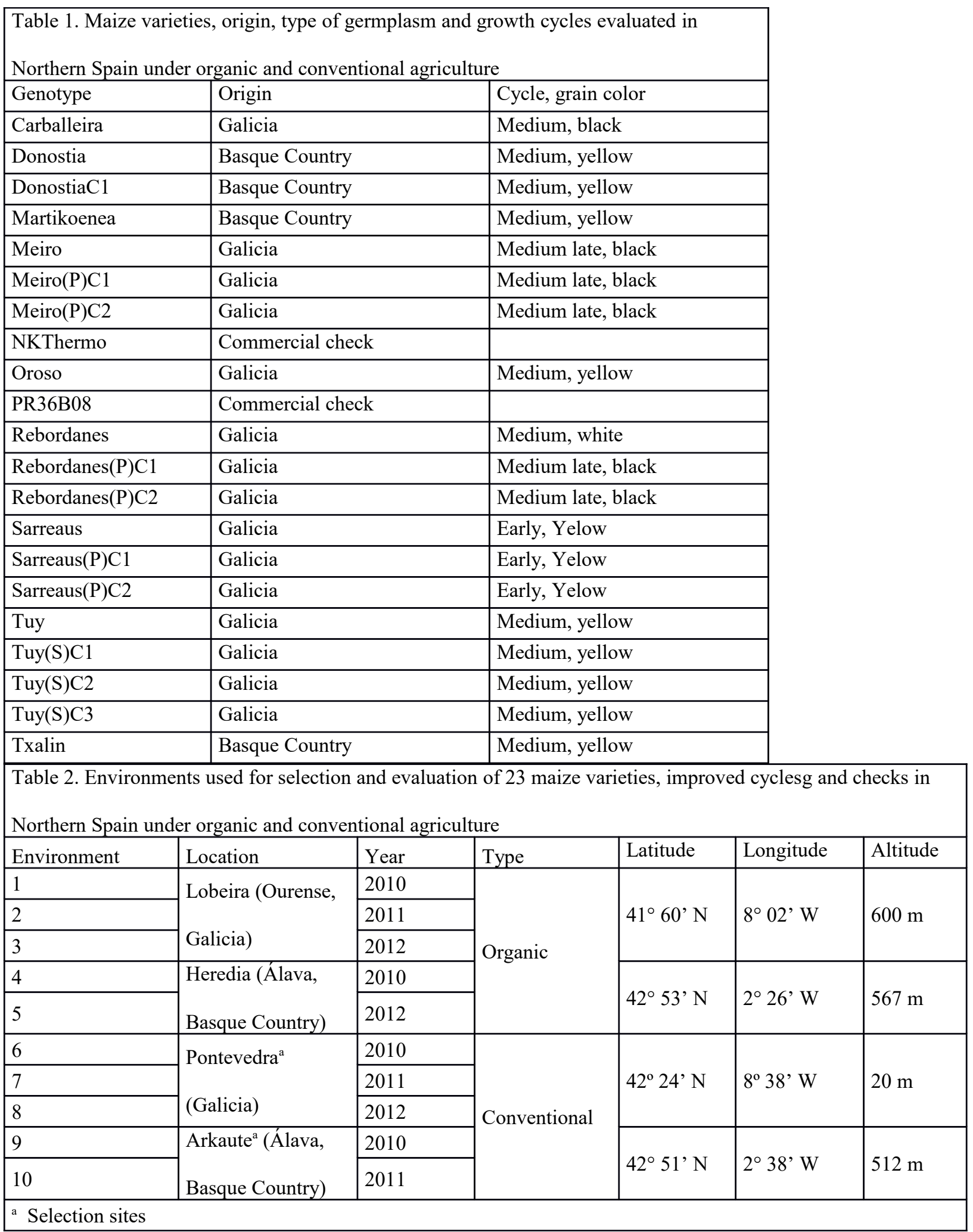




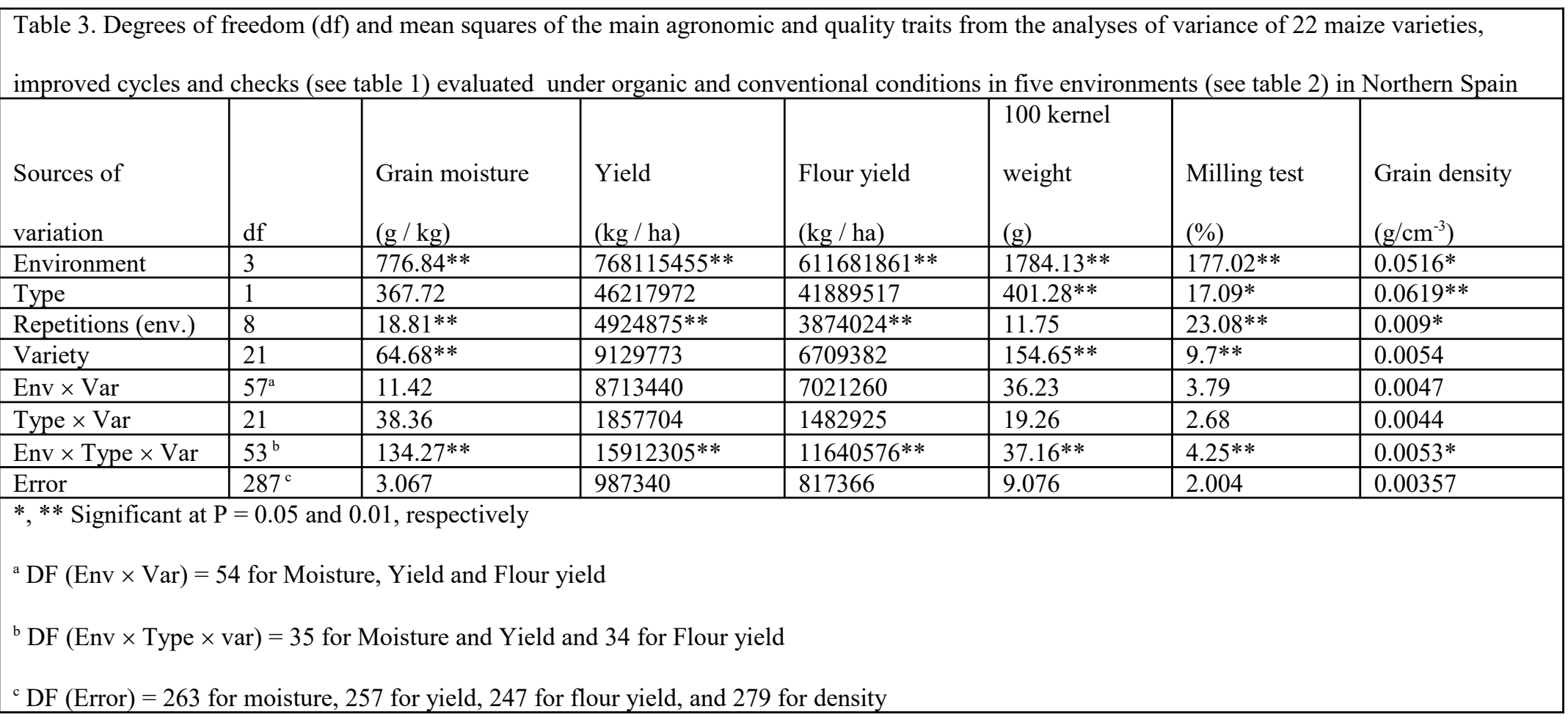

\begin{tabular}{l} 
Table 4. Mean ${ }^{\mathrm{a}}$ yield, flour yield ( $\mathrm{kg} \mathrm{ha}^{-1}$ at $140 \mathrm{~g} \mathrm{~kg}^{-1}$ grain moisture) and milling test (\% of grinds) for 22 maize \\
varieties, improved cycles and checks (see table 1) evaluated in five environments (see table 2) in Northern Spain \\
under organic (Org) in five environments under conventional (Con) agriculture and significant coefficients of \\
regression for cycles of selection \\
\hline \\
\hline
\end{tabular}




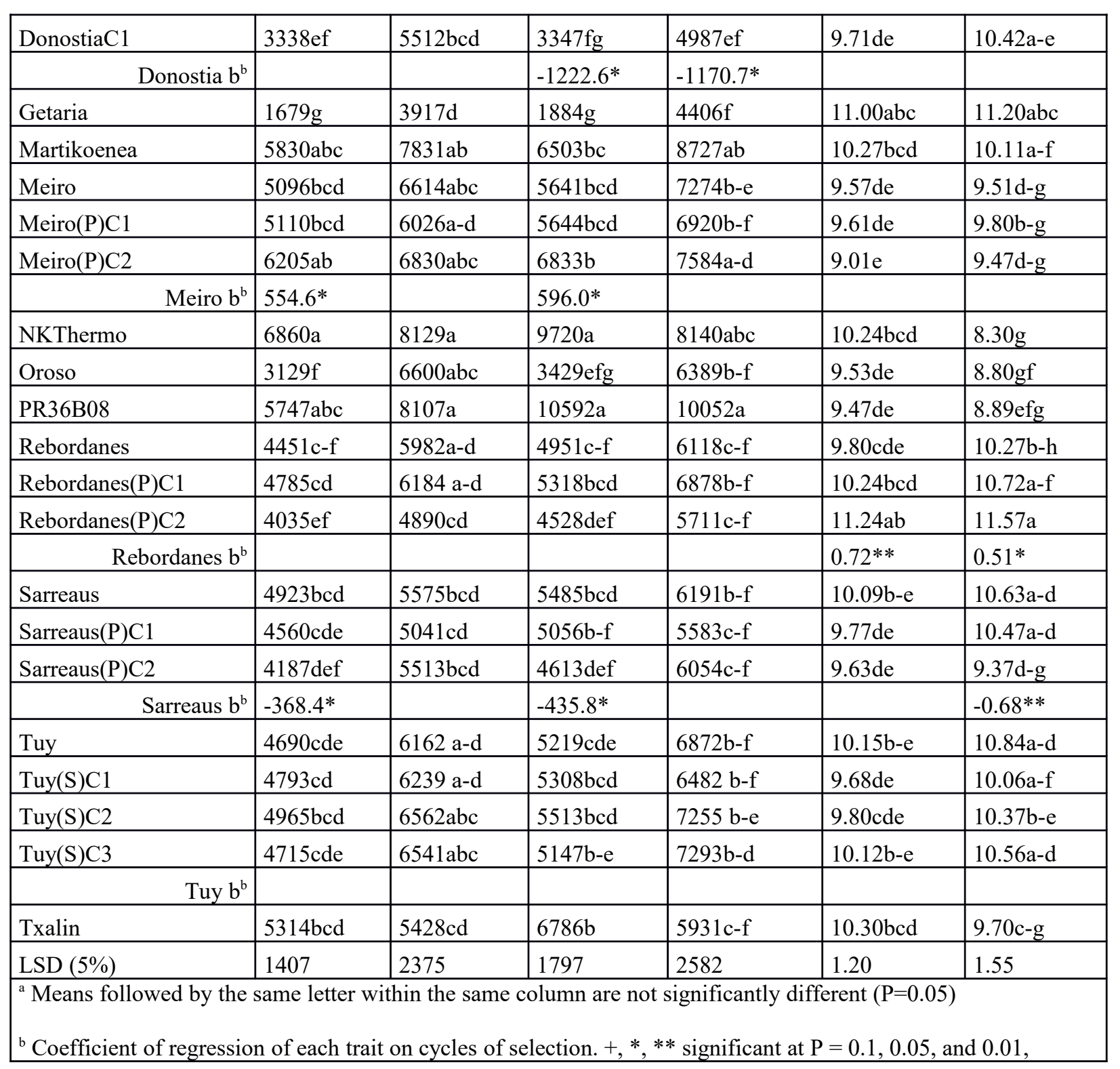


respectively

Table 5. Mean ${ }^{\mathrm{a}}$ yield $\left(\mathrm{Mg} \mathrm{ha}^{-1}\right.$ at $140 \mathrm{~g} \mathrm{~kg}^{-1}$ grain moisture) for 22 maize varieties, improved cycles and checks (see table 1) evaluated in ten environments (see

table 2) in Northern Spain under organic and conventional agriculture

\begin{tabular}{|c|c|c|c|c|c|c|c|c|c|c|}
\hline & Organic col & ditions & & & & Conventiol & $\mathrm{co}$ & & & \\
\hline Genotype & 1 & 2 & 3 & 4 & 5 & 6 & 7 & 8 & 9 & 10 \\
\hline Carballeira & 2966.7c & $2532.0 \mathrm{cde}$ & 2787.0a-d & 6999.7b-f & $5146.3 \mathrm{~h}$ & $881.7 \mathrm{a}-\mathrm{d}$ & & $5283.3 \mathrm{de}$ & $8167.0 \mathrm{cde}$ & 7491.3hg \\
\hline Donostia & $2717.0 \mathrm{c}$ & $1825.3 \mathrm{efg}$ & $1544.7 \mathrm{e}$ & 7936.3a-e & $8076.7 \mathrm{~g}$ & 1200.0a-d & & $2883.0 \mathrm{fg}$ & 9791.0abc & 8985.7fge \\
\hline DonostiaC1 & $3321.7 b c$ & $1200.7 \mathrm{~g}$ & $388.0 \mathrm{f}$ & 7135.3b-f & $8824.7 \mathrm{fg}$ & $99.5 \mathrm{~d}$ & & $1580.7 \mathrm{~g}$ & $8980.0 \mathrm{~b}-\mathrm{e}$ & $7660.0 \mathrm{hg}$ \\
\hline Getaria & & & 1884.0de & & & & & $4405.7 \mathrm{ef}$ & & \\
\hline Martikoenea & $2862.3 \mathrm{c}$ & $2110.7 d-g$ & & $9144.7 \mathrm{a}$ & $4689.3 \mathrm{~h}$ & $304.0 \mathrm{dc}$ & & & $9110.0 \mathrm{~b}-\mathrm{e}$ & $11151.7 \mathrm{c}$ \\
\hline Meiro & $4286.3 \mathrm{abc}$ & $3228.3 \mathrm{abc}$ & 2983.3a-d & 7610.0a-f & $11893.7 \mathrm{bc}$ & 1261.0a-d & & $7227.3 \mathrm{c}$ & 9427.0a-d & $11179.7 \mathrm{c}$ \\
\hline Meiro(P)C1 & $2739.7 \mathrm{c}$ & $3918.0 \mathrm{a}$ & 2219.7b-e & 7927.3a-e & 10098.3def & $1194.3 \mathrm{a}-\mathrm{d}$ & & $7770.3 \mathrm{c}$ & 9768.0abc & 8945.7fge \\
\hline Meiro(P)C2 & $5653.3 \mathrm{a}$ & $3640.7 \mathrm{ab}$ & $2884.3 \mathrm{a}-\mathrm{d}$ & $8520.0 \mathrm{ab}$ & $11413.7 \mathrm{cde}$ & $1042.7 \mathrm{a}-\mathrm{d}$ & & $9758.3 b$ & $8804.0 \mathrm{~b}-\mathrm{e}$ & $10728.7 \mathrm{c}$ \\
\hline NKThermo & & & & 7633.3a-e & $13468.3 \mathrm{ab}$ & $1834.3 \mathrm{ab}$ & & $12488.7 \mathrm{a}$ & $7167.0 \mathrm{e}$ & \begin{tabular}{|l|}
$11071.7 \mathrm{c}$ \\
\end{tabular} \\
\hline Oroso & $2774.3 \mathrm{c}$ & $1514.0 \mathrm{fg}$ & & $6000.0 \mathrm{fg}$ & $11807.3 \mathrm{bcd}$ & $532.7 \mathrm{bdc}$ & & & $10645.0 \mathrm{ab}$ & 7991.0fgh \\
\hline PR36B08 & & & & 6356.0efg & $14828.3 \mathrm{a}$ & $2185.0 \mathrm{a}$ & & $13248.0 \mathrm{a}$ & $8523.0 \mathrm{~b}-\mathrm{e}$ & $16251.3 \mathrm{a}$ \\
\hline Rebordanes & $3300.3 \mathrm{bc}$ & $2958.7 \mathrm{bcd}$ & $3118.3 \mathrm{abc}$ & $5353.3 \mathrm{~g}$ & $10026.0 \mathrm{ef}$ & 833.7a-d & & $6796.0 \mathrm{~cd}$ & $7174.0 \mathrm{e}$ & 9668.3dce \\
\hline Rebordanes $(\mathrm{P}) \mathrm{C} 1$ & 4169.0abc & 2403.0c-f & 2622.0a-e & $8354.3 \mathrm{ab}$ & $9042.3 \mathrm{fg}$ & 1091.0a-d & & $6394.3 \mathrm{~cd}$ & $11578.0 \mathrm{a}$ & $8449.3 \mathrm{e}-\mathrm{h}$ \\
\hline Rebordanes $(\mathrm{P}) \mathrm{C} 2$ & $2604.7 \mathrm{c}$ & 2234.5def & $2587.7 \mathrm{a}-\mathrm{e}$ & 6580.0d-g & $7869.3 \mathrm{~g}$ & $527.0 \mathrm{bcd}$ & & 5988.7cde & $8662.0 \mathrm{~b}-\mathrm{e}$ & 7667.0hg \\
\hline Sarreaus & $3561.0 \mathrm{bc}$ & 1981.0efg & $2035.7 \mathrm{cde}$ & 7748.7a-e & $12099.3 \mathrm{bc}$ & $521.0 \mathrm{bcd}$ & & 5934.0cde & $9249.0 \mathrm{~b}-\mathrm{e}$ & 9058.7d-g \\
\hline Sarreaus $(\mathrm{P}) \mathrm{C} 1$ & $3161.0 \mathrm{bc}$ & $2534.7 \mathrm{cde}$ & $2352.3 \mathrm{a}-\mathrm{e}$ & $6007.3 \mathrm{fg}$ & $11225.7 \mathrm{cde}$ & $1186.5 \mathrm{a}-\mathrm{d}$ & & $5203.7 \mathrm{de}$ & $7507.0 \mathrm{de}$ & $6969.7 \mathrm{~h}$ \\
\hline Sarreaus $(\mathrm{P}) \mathrm{C} 2$ & $3296.3 \mathrm{bc}$ & $1196.0 \mathrm{~g}$ & $1541.0 \mathrm{e}$ & $7679.7 a-e$ & 9354.0fg & $749.0 \mathrm{bcd}$ & & 4361.7ef & $9176.0 \mathrm{~b}-\mathrm{e}$ & $8161.7 \mathrm{e}-\mathrm{h}$ \\
\hline Tuy & $3066.7 \mathrm{c}$ & 1907.0efg & $3338.3 \mathrm{a}$ & $8800.3 \mathrm{a}$ & $8980.7 \mathrm{fg}$ & $1075.3 \mathrm{a}-\mathrm{d}$ & & $6359.3 \mathrm{~cd}$ & $10458.0 \mathrm{ab}$ & $9595.7 \mathrm{c}-\mathrm{f}$ \\
\hline Tuy(S)C1 & $3835.0 \mathrm{abc}$ & $2366.3 c-f$ & $2400.7 \mathrm{a}-\mathrm{e}$ & 7994.0a-d & 9943.3ef & $1502.3 \mathrm{a}-\mathrm{d}$ & & $6477.3 \mathrm{~cd}$ & 9161.0b-e & 8788.7efg \\
\hline Tuy(S)C2 & $5085.3 \mathrm{ab}$ & $2670.3 \mathrm{cde}$ & $3153.0 \mathrm{ab}$ & $8237.0 \mathrm{abc}$ & $8417.3 \mathrm{fg}$ & $603.3 \mathrm{bcd}$ & & 6046.0cde & $9433.0 \mathrm{a}-\mathrm{d}$ & $12938.0 \mathrm{~b}$ \\
\hline Tuy(S)C3 & $3522.0 \mathrm{bc}$ & $3176.3 \mathrm{abc}$ & $3011.3 \mathrm{abc}$ & $6667.0 \mathrm{c}-\mathrm{g}$ & 9358.3fg & $1098.0 \mathrm{a}-\mathrm{d}$ & & $7192.0 \mathrm{c}$ & $8167.0 \mathrm{cde}$ & $10648.7 \mathrm{dc}$ \\
\hline Txalin & $3223.7 \mathrm{bc}$ & & & $8488.7 \mathrm{ab}$ & $8645.3 \mathrm{fg}$ & $1549.3 \mathrm{abc}$ & & & 9209.0b-e & 7034.0h \\
\hline LSD $(0.05)$ & 1946.9 & 927.3 & 1100.3 & 1610.4 & 1739.4 & 1413.5 & & 1872.8 & 2163.5 & 1639.5 \\
\hline
\end{tabular}




\begin{tabular}{|c|c|c|c|c|c|c|c|c|c|c|}
\hline & & \multicolumn{4}{|c|}{ Organic conditions } & \multicolumn{5}{|c|}{ Conventional conditions } \\
\hline Genotype & 1 & 2 & 3 & 4 & 5 & 6 & 7 & 8 & 9 & 10 \\
\hline Carballeira & $11.74 b-e$ & $11.00 \mathrm{a}$ & 13.34 & 9.94 & 13.34 & $10.8 \mathrm{ab}$ & $13.20 \mathrm{a}$ & $13.94 \mathrm{a}$ & 9.94 & $9.26 b-f$ \\
\hline Donostia & $9.06 f$ & $8.66 b-f$ & 10.34 & 7.86 & 10.34 & $10.74 \mathrm{ab}$ & $11.00 \mathrm{bc}$ & $10.80 \mathrm{de}$ & 7.86 & $9.74 b-e$ \\
\hline DonostiaC1 & 10.06def & $8.86 \mathrm{~b}-\mathrm{e}$ & 12.20 & 8.54 & 12.20 & & $13.00 \mathrm{a}$ & $11.40 \mathrm{bcd}$ & 8.54 & $9.60 b-f$ \\
\hline Getaria & & & 11.00 & & & & & $11.20 \mathrm{cde}$ & & \\
\hline Martikoenea & $11.94 \mathrm{~b}-\mathrm{e}$ & $8.66 b-f$ & & 9.46 & 11.00 & $9.60 \mathrm{ab}$ & $10.26 \mathrm{~b}-\mathrm{e}$ & & 9.46 & $10.94 \mathrm{ab}$ \\
\hline Meiro & $11.46 \mathrm{~b}-\mathrm{e}$ & $6.60 \mathrm{f}$ & 10.86 & 8.06 & 10.86 & $8.34 \mathrm{bc}$ & $10.46 \mathrm{~b}-\mathrm{e}$ & $12.94 a-d$ & 8.06 & $7.74 \mathrm{f}$ \\
\hline Meiro(P)C1 & $11.2 \mathrm{fcde}$ & $7.14 \mathrm{def}$ & 11.06 & 7.60 & 11.06 & $9.14 \mathrm{ab}$ & $10.34 b-e$ & $12.80 \mathrm{a}-\mathrm{d}$ & 7.60 & $8.80 \mathrm{c}-\mathrm{f}$ \\
\hline Meiro(P)C2 & $9.66 \mathrm{ef}$ & $6.94 \mathrm{ef}$ & 10.06 & 8.34 & 10.06 & $8.60 \mathrm{bc}$ & $8.80 \mathrm{ef}$ & $11.60 \mathrm{bcd}$ & 8.34 & $10.00 \mathrm{~b}-\mathrm{e}$ \\
\hline NKThermo & $10.90 c-f$ & & & 9.80 & & $5.20 c$ & 8.94def & $8.00 \mathrm{f}$ & 9.80 & $8.54 \mathrm{def}$ \\
\hline Oroso & $12.20 \mathrm{bcd}$ & $8.66 b-f$ & & 7.74 & & $8.50 \mathrm{bc}$ & $10.90 \mathrm{bc}$ & & 7.74 & $8.66 c-f$ \\
\hline PR36B08 & & & & 9.46 & & $8.46 b c$ & $8.20 \mathrm{f}$ & $8.94 \mathrm{ef}$ & 9.46 & $10.40 a-d$ \\
\hline Rebordanes & $11.00 \mathrm{c}-\mathrm{f}$ & $7.46 \mathrm{c}-\mathrm{f}$ & 11.66 & 7.20 & 11.66 & $10.10 \mathrm{ab}$ & $10.54 \mathrm{bcd}$ & $13.06 a-d$ & 7.20 & $10.40 a-d$ \\
\hline $\begin{array}{l}\text { Rebordanes( } \\
\text { P)C1 }\end{array}$ & $11.80 \mathrm{~b}-\mathrm{e}$ & $9.26 \mathrm{abc}$ & 10.66 & 8.80 & 10.66 & $11.60 \mathrm{ab}$ & $10.60 \mathrm{bcd}$ & $13.60 \mathrm{ab}$ & 8.80 & $9.00 c-f$ \\
\hline $\begin{array}{l}\text { Rebordanes( } \\
\text { P)C2 }\end{array}$ & $13.60 \mathrm{ab}$ & $9.74 \mathrm{ab}$ & 12.00 & 8.86 & 12.00 & $12.66 \mathrm{a}$ & $11.66 \mathrm{ab}$ & $12.60 a-d$ & 8.86 & $12.30 \mathrm{a}$ \\
\hline Sarreaus & $10.46 \mathrm{c}-\mathrm{f}$ & $9.14 a-b$ & 11.14 & 8.60 & 11.14 & $12.60 \mathrm{a}$ & $10.00 \mathrm{~b}-\mathrm{e}$ & $12.34 \mathrm{a}-\mathrm{d}$ & 8.60 & $9.60 b-f$ \\
\hline $\begin{array}{l}\text { Sarreaus(P) } \\
\mathrm{C} 1\end{array}$ & $11.20 \mathrm{c}-\mathrm{f}$ & $9.14 a-b$ & 10.26 & 8.00 & 10.26 & $11.80 \mathrm{ab}$ & $11.00 \mathrm{bc}$ & $12.66 a-d$ & 8.00 & $8.86 \mathrm{c}-\mathrm{f}$ \\
\hline $\begin{array}{l}\text { Sarreaus }(\mathrm{P}) \\
\mathrm{C} 2\end{array}$ & $10.26 \mathrm{def}$ & $9.66 \mathrm{ab}$ & 10.26 & 7.66 & 10.26 & $9.00 \mathrm{~b}$ & $9.30 \mathrm{c}-\mathrm{f}$ & $11.54 \mathrm{bcd}$ & 7.66 & $9.20 b-f$ \\
\hline Tuy & 10.26def & $9.40 \mathrm{abc}$ & 11.14 & 8.80 & 11.14 & $10.46 \mathrm{ab}$ & $11.66 \mathrm{ab}$ & $12.74 a-d$ & 8.80 & $10.54 \mathrm{abc}$ \\
\hline Tuy(S)C1 & $10.54 c-f$ & $8.66 \mathrm{~b}-\mathrm{f}$ & 10.40 & 8.40 & 10.40 & $9.00 \mathrm{~b}$ & $10.14 \mathrm{~b}-\mathrm{e}$ & $13.26 \mathrm{abc}$ & 8.40 & $9.14 b-f$ \\
\hline Tuy(S)C2 & 9.94def & $8.20 b-f$ & 11.14 & 8.60 & 11.14 & 10.94ab & $11.14 \mathrm{~b}$ & $12.40 \mathrm{a}-\mathrm{d}$ & 8.60 & $8.80 \mathrm{c}-\mathrm{f}$ \\
\hline
\end{tabular}




\begin{tabular}{|l|l|l|l|l|l|l|l|l|l|l|}
\hline Tuy(S)C3 & $14.60 \mathrm{a}$ & $9.14 \mathrm{a}-\mathrm{d}$ & 10.20 & 9.46 & 10.20 & $11.30 \mathrm{ab}$ & $10.66 \mathrm{bc}$ & $11.40 \mathrm{bcd}$ & 9.46 & $10.20 \mathrm{~b}-\mathrm{e}$ \\
\hline Txalin & $12.74 \mathrm{abc}$ & & & 7.86 & & $11.74 \mathrm{ab}$ & $13.00 \mathrm{a}$ & & 7.86 & $8.40 \mathrm{ef}$ \\
\hline LSD $(0.05)$ & 2.32 & 2.10 & & & & 3.58 & 1.72 & 2.30 & & 1.94 \\
\hline
\end{tabular}

2 


\begin{tabular}{|c|c|c|c|c|c|c|c|c|c|c|c|c|c|}
\hline \multirow[b]{2}{*}{ Genotype } & \multicolumn{3}{|c|}{ Plan apperance (1-9) } & \multicolumn{2}{|c|}{ Silking (days) } & \multicolumn{2}{|c|}{ Ears per plant } & \multicolumn{2}{|c|}{ Grain moisture (\%) } & \multicolumn{2}{|c|}{100 grain weight $(\mathrm{g})$} & \multicolumn{2}{|c|}{$\begin{array}{l}\text { Grain density (g } \\
\left.\mathrm{cm}^{-3}\right)\end{array}$} \\
\hline & Con & Org & Con & Org & Con & Org & Con & Org & Con & Org & Con & Org & Con \\
\hline BastoxBlanco & & $3.7 \mathrm{cde}$ & & 78.7 & & & & $22.6 \mathrm{~cd}$ & & & & & \\
\hline Carballeira & 3.3 & $3.7 \mathrm{cde}$ & 4.0 & 69.8 & $82.8 \mathrm{ab}$ & 0.78 & $0.88 \mathrm{a}$ & $\begin{array}{l}21.8 \mathrm{de} \\
\mathrm{f}\end{array}$ & $20.7 \mathrm{e}-\mathrm{i}$ & $32.7 \mathrm{c}-\mathrm{f}$ & $35.1 \mathrm{f}-\mathrm{i}$ & 1.23 & $1.26 \mathrm{ab}$ \\
\hline Donostia & 2.7 & $3.3 \mathrm{e}$ & 3.2 & 72.0 & $73.5 \mathrm{gh}$ & 0.80 & $0.91 \mathrm{a}$ & $\begin{array}{l}21.0 \mathrm{e}- \\
\mathrm{h}\end{array}$ & $21.4 \mathrm{~d}-\mathrm{h}$ & $36.3 \mathrm{ab}$ & $39.8 b$ & 1.14 & $1.25 \mathrm{abc}$ \\
\hline DonostiaC1 & 3.0 & $2.3 \mathrm{f}$ & 2.5 & 67.8 & $71.9 \mathrm{gh}$ & 0.55 & $0.54 \mathrm{c}$ & $\begin{array}{l}20.8 \mathrm{fg} \\
\mathrm{h} \\
\end{array}$ & $19.7 \mathrm{ij}$ & $36.1 \mathrm{ab}$ & $39.7 b$ & 1.20 & $1.25 \mathrm{a}-\mathrm{d}$ \\
\hline Getaria & & & & & $81.7 \mathrm{abc}$ & 0.95 & $1.03 \mathrm{a}$ & $36.4 \mathrm{a}$ & $23.2 \mathrm{abc}$ & $29.5 \mathrm{gh}$ & $40.2 \mathrm{~b}$ & 1.12 & $1.20 \mathrm{gh}$ \\
\hline Meiro & 3.8 & $4.5 \mathrm{ab}$ & 4.3 & 68.0 & $80.0 \mathrm{~b}-\mathrm{e}$ & 0.74 & $0.92 \mathrm{a}$ & $24.0 \mathrm{c}$ & $21.4 \mathrm{~d}-\mathrm{h}$ & $31.8 \mathrm{~d}-\mathrm{g}$ & $35.2 \mathrm{f}-\mathrm{i}$ & 1.18 & $1.24 \mathrm{a}-\mathrm{e}$ \\
\hline Meiro(P)C1 & 3.5 & $4.5 \mathrm{ab}$ & 4.5 & 75.5 & $86.6 \mathrm{a}$ & 0.81 & $0.96 \mathrm{a}$ & $26.0 \mathrm{~b}$ & $24.1 \mathrm{a}$ & $28.2 \mathrm{hi}$ & 33.6hij & 1.20 & $1.30 \mathrm{a}$ \\
\hline Meiro(P)C2 & 3.3 & $4.5 \mathrm{ab}$ & 4.7 & 77.8 & $80.8 \mathrm{a}-\mathrm{e}$ & 0.75 & $0.95 \mathrm{a}$ & $26.2 \mathrm{~b}$ & $23.4 \mathrm{ab}$ & $30.9 \mathrm{~d}-\mathrm{h}$ & 34.9ghi & 1.17 & $1.20 \mathrm{c}-\mathrm{f}$ \\
\hline NKThermo & 3.5 & $4.7 \mathrm{a}$ & 4.3 & 78.3 & $79.5 \mathrm{~b}-\mathrm{f}$ & & $1.03 \mathrm{a}$ & $18.0 \mathrm{k}$ & $21.1 \mathrm{~d}-\mathrm{h}$ & $30.5 \mathrm{e}-\mathrm{h}$ & $32.0 \mathrm{j}$ & 1.17 & $1.16 \mathrm{~h}$ \\
\hline Oroso & 3.7 & $4.3 \mathrm{abc}$ & 4.7 & 78.0 & $81.4 \mathrm{a}-\mathrm{d}$ & 0.74 & $0.85 \mathrm{ab}$ & $23.9 \mathrm{c}$ & $24.0 \mathrm{a}$ & $33.6 \mathrm{bcd}$ & $33.4 \mathrm{ji}$ & 1.23 & $1.21-\mathrm{cf}$ \\
\hline PR36B08 & 3.5 & $3.8 \mathrm{~b}-\mathrm{e}$ & 3.7 & 79.7 & $81.3 \mathrm{a}-\mathrm{d}$ & & $1.04 \mathrm{a}$ & $19.0 \mathrm{jk}$ & $21.6 \mathrm{~d}-\mathrm{g}$ & $30.6 \mathrm{e}-\mathrm{h}$ & $35.5 \mathrm{fg}$ & 1.15 & $1.20 \mathrm{f}-\mathrm{h}$ \\
\hline Rebordanes & 3.2 & $4.27 \mathrm{a}-\mathrm{d}$ & 3.7 & 75.5 & $76.8 \mathrm{c}-\mathrm{g}$ & 0.70 & $0.86 \mathrm{ab}$ & $\begin{array}{l}\text { 21.8d- } \\
\mathrm{g} \\
\end{array}$ & $21.4 \mathrm{~d}-\mathrm{h}$ & $35.4 \mathrm{abc}$ & $39.5 \mathrm{cb}$ & 1.20 & $1.23 \mathrm{a}-\mathrm{f}$ \\
\hline Rebordanes $(\mathrm{P}) \mathrm{C} 1$ & 3.8 & $4.27 \mathrm{a}-\mathrm{d}$ & 4.2 & 75.5 & $79.9 \mathrm{~b}-\mathrm{e}$ & 0.75 & $0.95 \mathrm{a}$ & $22.9 \mathrm{~cd}$ & $21.5 \mathrm{~d}-\mathrm{g}$ & $32.6 \mathrm{c}-\mathrm{f}$ & $35.4 \mathrm{fgh}$ & 1.19 & $1.23 \mathrm{~d}-\mathrm{f}$ \\
\hline Rebordanes $(\mathrm{P}) \mathrm{C} 2$ & 3.3 & $2.0 \mathrm{f}$ & 3.2 & 76.3 & $81.0 \mathrm{a}-\mathrm{e}$ & 0.76 & $0.93 \mathrm{a}$ & $23.8 \mathrm{c}$ & $21.4 \mathrm{~d}-\mathrm{h}$ & $31.8 \mathrm{~d}-\mathrm{g}$ & $35.0 \mathrm{f}-\mathrm{i}$ & 1.19 & $1.24 \mathrm{a}-\mathrm{e}$ \\
\hline Sarreaus & 3.3 & $4.5 \mathrm{ab}$ & 4.0 & 70.7 & $71.9 \mathrm{gh}$ & 0.72 & $0.83 \mathrm{ab}$ & $20.7 \mathrm{f}-\mathrm{i}$ & $19.2 \mathrm{j}$ & $33.4 \mathrm{~b}-\mathrm{e}$ & $35.4 \mathrm{fgh}$ & 1.18 & $1.23 \mathrm{~b}-\mathrm{f}$ \\
\hline Sarreaus $(\mathrm{P}) \mathrm{C} 1$ & 3.2 & $3.5 \mathrm{de}$ & 3.3 & 74.2 & $70.2 \mathrm{~h}$ & 0.77 & $0.79 \mathrm{abc}$ & $20.7 \mathrm{f}-\mathrm{i}$ & $20.5 f-j$ & $30.2 \mathrm{fgh}$ & 34.0ghi & 1.19 & $1.21 \mathrm{c}-\mathrm{f}$ \\
\hline
\end{tabular}




\begin{tabular}{|l|l|l|l|l|l|l|l|l|l|l|l|l|l|}
\hline & & & & & & & & f & & & & & \\
\hline Tuy(S)C1 & 3.7 & $4.3 \mathrm{abc}$ & 4.2 & 72.8 & $76.2 \mathrm{c}-\mathrm{g}$ & 0.72 & $1.00 \mathrm{a}$ & $22.6 \mathrm{~cd}$ & $22.1 \mathrm{bcd}$ & $35.4 \mathrm{abc}$ & $39.3 \mathrm{bc}$ & 1.19 & $1.21 \mathrm{def}$ \\
\hline & & & & & & & & $22.6 \mathrm{~cd}$ & & & & & \\
& & & & & & & & & & & & \\
Tuy(S)C2 & 3.0 & $3.8 \mathrm{~b}-\mathrm{e}$ & 3.8 & 70.3 & $76.1 \mathrm{c}-\mathrm{g}$ & 0.77 & $0.92 \mathrm{a}$ & $\mathrm{e}$ & $22.0 \mathrm{cde}$ & $36.0 \mathrm{ab}$ & $38.4 \mathrm{bcd}$ & 1.19 & $1.21 \mathrm{edf}$ \\
\hline Tuy(S)C3 & 3.8 & $3.8 \mathrm{~b}-\mathrm{e}$ & 3.8 & 73.0 & $75.4 \mathrm{e}-\mathrm{h}$ & 0.91 & $1.06 \mathrm{a}$ & $22.9 \mathrm{~cd}$ & $20.9 \mathrm{~d}-\mathrm{i}$ & $34.9 \mathrm{abc}$ & $37.7 \mathrm{cde}$ & 1.20 & $1.2 \mathrm{~b}-\mathrm{f}$ \\
\hline Txalin & 3.3 & $4.3 \mathrm{abc}$ & 3.8 & 70.8 & $73.8 \mathrm{fgh}$ & & $0.59 \mathrm{bc}$ & $19.2 \mathrm{ijk}$ & $20.3 \mathrm{~g}-\mathrm{j}$ & $36.2 \mathrm{ab}$ & $35.8 \mathrm{efg}$ & 1.21 & $1.21 \mathrm{efg}$ \\
\hline
\end{tabular}




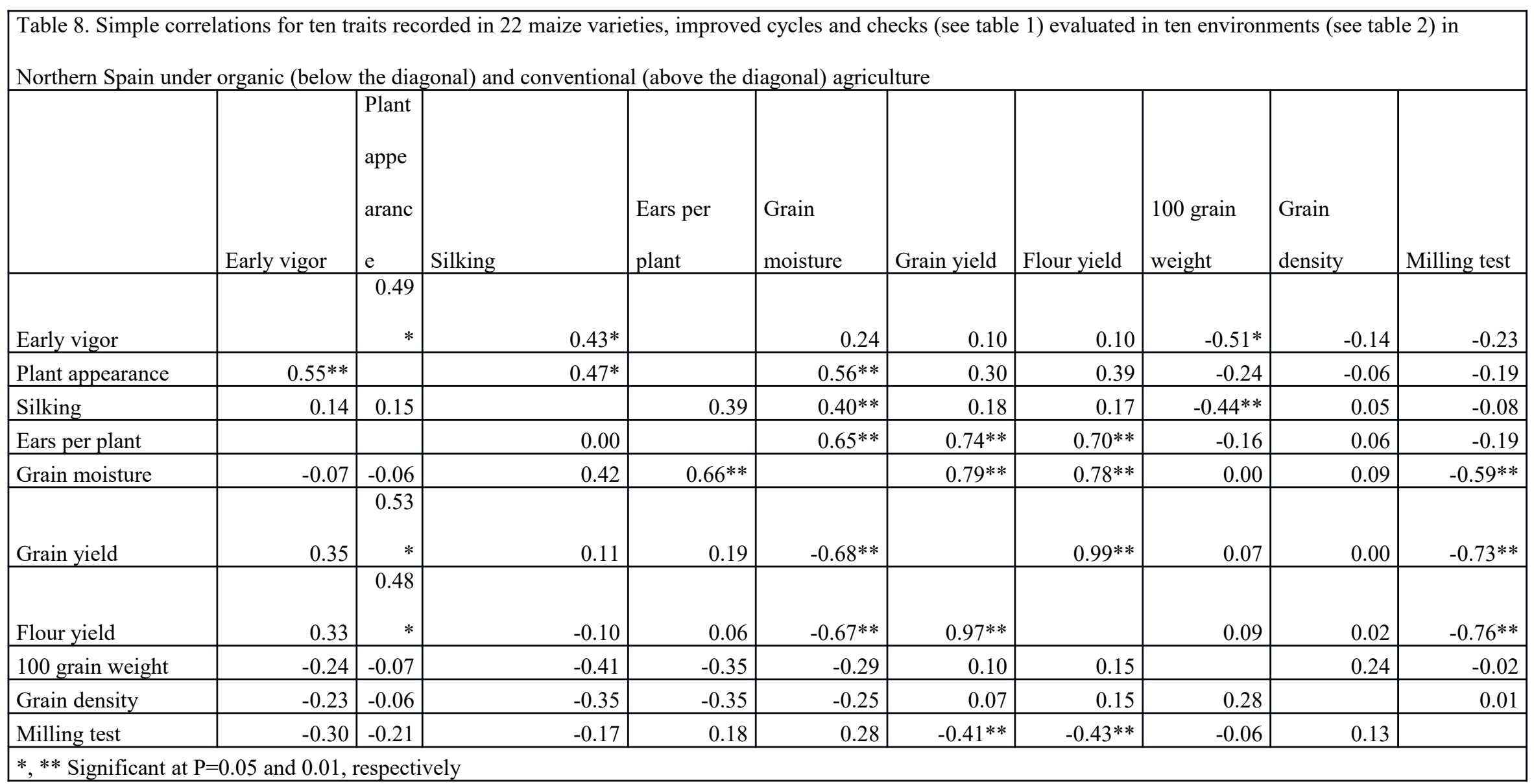

